\title{
LIQUID IRON DEOXIDATION BY ALUMINUM: A BRIEF REVIEW OF EXPERIMENTAL DATA AND THERMODYNAMIC DESCRIPTION
}

\author{
André Luiz Vasconcellos da Costa e Silva ' \\ Flávio Beneduce Neto ${ }^{2}$ \\ Roberto Ribeiro de Avillez ${ }^{3}$
}

\begin{abstract}
The iron-oxygen-aluminum equilibrium has been a subject of interest for many years due to its importance in the steel industry. A great percentage of all flat rolled steel is aluminum killed "AK" (deoxidized) low-carbon steel, not only because of the low soluble oxygen contents that can be achieved but also because of the importance of the residual aluminum in forming aluminum nitride that is one of the main tools used to achieve crystallographic texture adequate for forming. The behavior both of oxygen and of aluminum in liquid iron are relatively well understood and quantified, as is the free energy of formation of alumina. Nonetheless, the Fe-Al-O behavior at liquid iron temperatures is not fully understood and considerable controversy still prevails. Thus, the objectives of this work are (a) to critically review the experimental work and assessments performed mainly on the $\mathrm{Al}-\mathrm{Fe}-\mathrm{O}-\mathrm{Al}_{2} \mathrm{O}_{3}$ equilibrium, (b) to evaluate the current models used to describe this equilibrium and (c) to present a recommendation about the data, based on its evaluated reliability and consistency. Keywords: Steel; Deoxidation; Thermodynamics; Al-Fe-O system; CALPHAD.
\end{abstract}

\section{DESOXIDAÇÃO DO FERRO LÍQUIDO POR ALUMÍNIO: UMA BREVE REVISÃO DOS DADOS EXPERIMENTAIS E DESCRIÇÕES TERMODINÂMICAS}

\section{Resumo}

O sistema ferro-oxigênio alumino tem sido investigado há muitos anos em função de sua importância para a indústria do aço. Uma grande fração de todo o aço plano produzido é de aço de baixo carbono acalmado ao alumínio, não apenas pelo baixo conteúdo de oxigênio residual em solução que pode ser obtido, mas, também, pela importância do alumínio residual na formação de AIN, importante no controle de estrutura e textura obtidas. Tanto o comportamento do oxigênio como o do alumínio no ferro líquido são relativamente bem compreendidos e quantificados, assim como a propriedades termodinâmicas da alumina. Entretanto, há discrepâncias significativas na quantificação do comportamento do sistema Fe-Al-O na tempertura do aço líquido, havendo, ainda, bastante controvérsia com respeito a equilíbrios importantes neste sistema. Assim, o objetivo deste trabalho é (a) realizar uma revisão crítica dos experimentos e avaliações termodinâmicas principalmente do equilíbrio $\mathrm{Al}-\mathrm{Fe}-\mathrm{O}-\mathrm{Al}_{2} \mathrm{O}_{3}(\mathrm{~b})$ avaliar os métodos atualmente usados para descrever este equilíbrio e (c) apresentar recomendações sobre os dados, com base em sua confiabilidade e consistência.

Palavras-chave: Aço; Desoxidação; Termodinâmica; Sistema Al-Fe-O; CALPHAD.

\section{INTRODUCTION}

The iron-oxygen-aluminum equilibrium has been a subject of interest for many years due to its importance to the steel industry. A great percentage of all flat rolled steel is aluminum killed "AK" (deoxidized) low-carbon steel, not only because of the low soluble oxygen contents that can be achieved but also because of the importance of the residual aluminum in forming aluminum nitride that is one of the main tools used to achieve crystallographic texture adequate for forming [I]. For many years, aluminum has also been an important alloying addition at relatively high levels in steels used for nitriding, such as Nitralloy ${ }^{\circledR}$ or W.Nr. I 8550 (about $1 \% \mathrm{Al}$ ). High Mn-Al steels (such as 20Mn23AIV, 23\%Mn,

'Escola de Engenharia Industrial Metalúrgica de Volta Redonda - EEIMVR, Universidade Federal Fluminense - UFF, Volta Redonda, RJ, Brazil.

E-mail:andre@metal.eeimvr.uff.br

${ }^{2}$ Escola Politécnica, Universidade de São Paulo - USP, São Paulo, SP, Brazil.

${ }^{3}$ Departamento de Engenharia Química e de Materiais, Pontifícia Universidade Católica do Rio de Janeiro - PUC-Rio, Rio de Janeiro, RJ, Brazil. 
2\%Al) [2] are used for electrical purposes and, in recent years, the prospect of producing lower density steels for the automotive industry through the use of significant additions of aluminum has been the subject of many studies [3,4]. Aluminum usage for deoxidation in typical flat products mill making "standard" steels ranges from 1.3 to $2 \mathrm{~kg} / \mathrm{t}$, which represents a significant part of the alloy addition costs in these plants [5].

The behavior of oxygen in liquid iron is relatively well understood and quantified, as is the behavior of aluminum in iron. Even though the Gibbs Energy of formation of the aluminum oxides is also well established, the understanding of the $\mathrm{Al}-\mathrm{Fe}-\mathrm{O}$ equilibrium in liquid steel has been studied in detail since at least 1950 [6] until the last decade [7] and considerable controversy still prevails. Two of the main reasons for this are that the measurement of the Al-Fe-O equilibria at steelmaking temperatures involves extremely low oxygen potentials and the difficulties in the chemical analysis of the true content of oxygen dissolved in the alloy. Thus, the objectives of this work are (a) to critically review the experimental work and assessments performed mainly on the $\mathrm{Al}-\mathrm{Fe}-\mathrm{O}-\mathrm{Al}_{2} \mathrm{O}_{3}$ equilibrium, (b) to evaluate the current models used to describe this equilibrium and (c) to present a recommendation about the data, based on its evaluated reliability and consistency.

\section{REVIEW OF PREVIOUS WORK}

\section{I Possible Sources of Error in Experimental Work}

When evaluating the various publications dealing with the equilibrium with $\mathrm{Al}_{2} \mathrm{O}_{3}$ in the iron rich corner of the Al-Fe-O system it is interesting to review the various possible sources of experimental errors, as summarized in
Table I, most of which have been discussed during the years since the pioneering work of Hilty and Crafts [6].

\subsection{Thermodynamic Modeling and the Interaction Between the Solutes}

It has been observed for quite some time [ 10$]$ that for strong deoxidants in iron, the equilibrium Henryan activity curves show significant discrepancies from the equilibrium plots of concentration, as schematically shown in Figure I for the chromium oxygen equilibrium in liquid iron at $1600^{\circ} \mathrm{C}$.

Most of the modeling work describing this equilibrium has been based on Wagner's dilute solution formalism [ I I]. In this formalism, interaction parameters are used to account for deviations from Henry's law caused by deviation from extremely dilute solutions and by the interaction between the solutes in the liquid phase. Several authors have discussed the limitations of this formalism (see, for instance [12-14]). Fruehan [15] has probably been the first author to call the attention to these limitations specifically in the Fe-Al-O system, albeit he mentions the fact that Lupis and Elliott [16] had already addressed the general aspects of the problem.

An evident conclusion of these remarks and discussions is that the dilute solution formalism predictions increasingly deviate from reality as the solutes significantly depart from dilute solution.

Later, Pelton and Bale [17] proposed an alternative approach to Wagner's formalism, and currently, with the solution models used in computational thermodynamics, these limitations can be completely eliminated $[18,19]$. For this reason, the works of St. Pierre [20] and others, in which the effects of the different interaction coefficients on the shape of the solubility curve of alumina are discussed, are not reviewed here.

Table I. Most important sources of error in determination of equilibrium with $\mathrm{Al}_{2} \mathrm{O}_{3}$ in Fe rich alloys

\begin{tabular}{|c|c|c|}
\hline Source of error & Comment & $\begin{array}{l}\text { First Discussed } \\
\text { by }\end{array}$ \\
\hline Analytical techniques for oxygen in iron & The expected minimum values are lower than I0ppm of oxygen. & Hilty and Crafts [6] \\
\hline Analytical techniques for aluminum in iron & $\begin{array}{l}\text { In the high oxygen range (in special when hercynite becomes stable), the } \\
\text { expected aluminum contents in the liquid are very low. }\end{array}$ & Hilty and Crafts [6] \\
\hline $\begin{array}{l}\text { Equilibrium achieved with oxide other than } \\
\mathrm{Al}_{2} \mathrm{O}_{3} \text { without knowledge of the authors }\end{array}$ & $\begin{array}{l}\text { Due to the reactivity of aluminum and of oxygen, many experimental setups/ } \\
\text { procedures create opportunities for equilibrium to be reached with oxides } \\
\text { other than } \mathrm{Al}_{2} \mathrm{O}_{3} \text {. }\end{array}$ & Hilty and Crafts [6] \\
\hline $\begin{array}{l}\text { Contamination of sample due to atmosphere } \\
\text { or refractories }\end{array}$ & $\begin{array}{l}\text { In some experiments when the authors expect to closely control the oxygen } \\
\text { potential inside the furnace (as opposed to simply measure the results) } \\
\text { secondary reactions and purity issues may affect the results. }\end{array}$ & Hilty and Crafts [6] \\
\hline Presence of primary particles floating in the melt & $\begin{array}{l}\text { If the experiment is conducted as a deoxidation experiment, } \mathrm{Al}_{2} \mathrm{O}_{3} \text { formed } \\
\text { during the experiment might not float completely out of the melt and result } \\
\text { in error. Should not be confused with secondary } \mathrm{Al}_{2} \mathrm{O}_{3} \text { that will precipitate } \\
\text { as the sample cools but represents } \mathrm{Al} \text { and } \mathrm{O} \text { that were in solution at the } \\
\text { experiment temperature. }\end{array}$ & Hilty and Crafts [6] \\
\hline Nucleation of alumina in the melt & $\begin{array}{l}\text { Depending on the type of experiment (adding } \mathrm{Al} \text { to an oxidized melt or } \\
\text { dissolving } \mathrm{Al}_{2} \mathrm{O}_{3} \text {, for instance), nucleation can be a barrier to equilibrium. }\end{array}$ & $\begin{array}{l}\text { Schenk et al. [8], } \\
\text { Rohde et al. [9] }\end{array}$ \\
\hline Time for equilibration & $\begin{array}{l}\text { The time for equilibration depends on many factors including size of samples, } \\
\text { agitation, etc. }\end{array}$ & $\begin{array}{l}\text { Hilty and Crafts } \\
{[6], \text { Kang et al. [7] }}\end{array}$ \\
\hline
\end{tabular}


One important and unfortunate fact is that, to date, there is no way to predict to which extent the formalism can be accurately applied in a given system.

However, not surprisingly, when the Wagner dilute solution formalism is used, the values of the interaction coefficients do express, somehow, the affinity between the deoxidizer and oxygen, as shown in Figure 2. This indicates that the interaction coefficients do have some physicochemical significance.

One important effect of the use of interaction coefficients is that, when the interaction between oxygen and deoxidant is sufficiently strong, the equilibrium composition curve passes through a minimum, discussed by many authors $[14,20]$. Kuo [2I], for instance, has shown that the position and value of this minimum depend strongly on the value of the interaction coefficient $e_{O}^{A l}$.

On the other hand, when analyzing the Fe-Ca-O system, Hillert et al. [22] considered that the apparent interaction, expressed by the Wagner interaction coefficient,

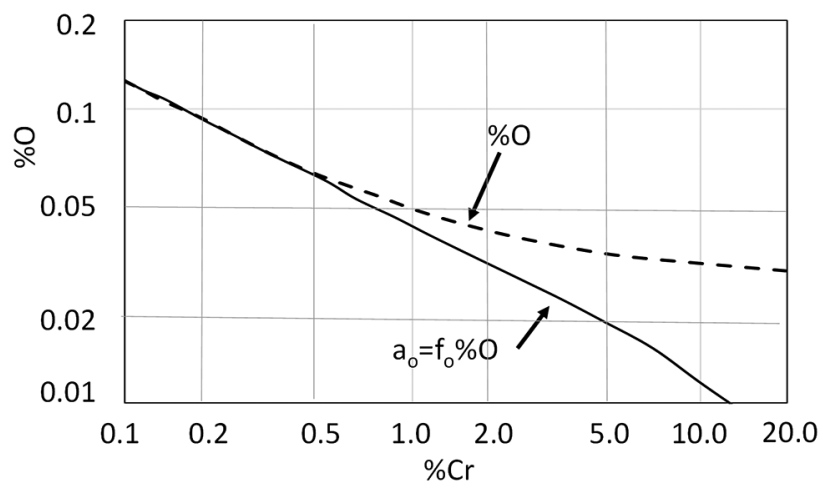

Figure I. Discrepancy between oxygen and chromium Henryan activities and chemical composition in equilibrium with oxide, as proposed in 1949 by Chipman [10] for the chromium-oxygen equilibrium at $1595^{\circ} \mathrm{C}$ in iron (The notation used by Chipman, $\mathrm{a}_{\mathrm{o}}$ instead of $\mathrm{h}_{\mathrm{o}}$ was preserved).

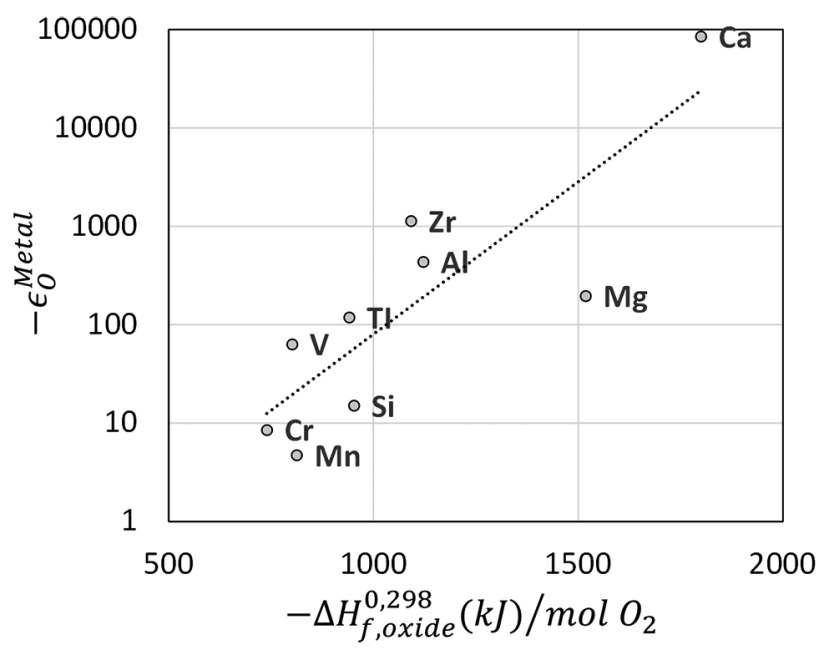

Figure 2. First order interaction coefficient $\varepsilon_{O}^{\text {Metal }}$ versus enthalpy change for the formation of the metal oxide, per mol of $\mathrm{O}_{2}$. Interactions coefficients from [13] except for $\mathrm{Ca}$ and $\mathrm{Mg}$, calculated according [23] from $e_{O}^{\text {Metal }}$ given by [24]. Enthalpies from [25]. was excessive. Later Hillert and Selleby [26] proposed that this was due to "a serious systematic error" on the experimental determination of the oxide solubilities. By relating the sub-lattice model equations for regular solutions to the dilute solution formalism, they calculated $\varepsilon_{O}^{A l}$ from the information on the $\mathrm{Fe}-\mathrm{O}$ and Fe-Al binary systems, together with the free energy of formation of $\mathrm{Al}_{2} \mathrm{O}_{3}$. They suggested that the interaction coefficient in the Fe-Al-O system should be $e_{O}^{A l}=-0.11$ at $1600^{\circ} \mathrm{C}$, a value much lower than the values determined experimentally by most authors, as will be discussed in the next section.

\subsection{Review of Experimental Work}

In this section, the experimental work on the Fe-Al-O- $\mathrm{Al}_{2} \mathrm{O}_{3}$ equilibrium is reviewed following as much as possible their chronological order, to emphasize how the different sources of error identified in Table I were dealt with by different authors as they learned from previous works. The possible sources of errors listed in Table I are highlighted in the context of each work reviewed.

Hilty and Crafts [6] were probably the first authors to have access to reliable analytical techniques for measuring the content of $\mathrm{Al}$ and $\mathrm{O}$ present in steel. Since their results deviated too much from the theoretically calculated values, they speculated that the deviation was due to achievement of equilibrium with other oxides instead of pure $\mathrm{Al}_{2} \mathrm{O}_{3}$. In the discussion of this paper, Chipman proposed that this oxide could be hercynite, $\mathrm{FeO} \cdot \mathrm{Al}_{2} \mathrm{O}_{3}$. Also in the discussion, both J. Elliott and N.A. Gokcen speculate that an additional source of oxygen might be contaminating the atmosphere. Furthermore, the authors reported that they have observed extensive reaction between the crucible (that was supposed to be pure $\mathrm{Al}_{2} \mathrm{O}_{3}$ ) and the melt. It is conceivable that lower stability oxides might have been present in the raw material they have used for making the crucible, which, as observed in other experiments, can be a significant source of oxygen and affect the possibility of reaching equilibrium [27].

At their time, Hilty and Crafts estimated the precision of vacuum fusion analysis of oxygen at $10 \mathrm{ppm}$, which, for their results, was not relevant, due to the possible equilibrium with hercynite and not alumina. The estimated precision of their colorimetric method for aluminum was better than I ppm. Therefore, at this time, the question of the precision and limitation of the analytical method was only applicable to oxygen.

After the work of Hilty and Crafts, Gokcen and Chipman [28] performed experiments under carefully controlled $\mathrm{H}_{2} / \mathrm{H}_{2} \mathrm{O}$ atmospheres and pure alumina crucibles (no information on exact purity or source) to try to control sources of oxygen contamination. Through careful analysis of all measurable data and consistency checks with thermodynamic values, they were able to measure equilibrium with $\mathrm{Al}_{2} \mathrm{O}_{3}$ and to estimate the interaction coefficient of $\mathrm{Al}$ and $\mathrm{O}$ in liquid iron. They showed how their precision in oxygen analysis of $\pm 5 \mathrm{ppm}$ affected the results and the estimated 


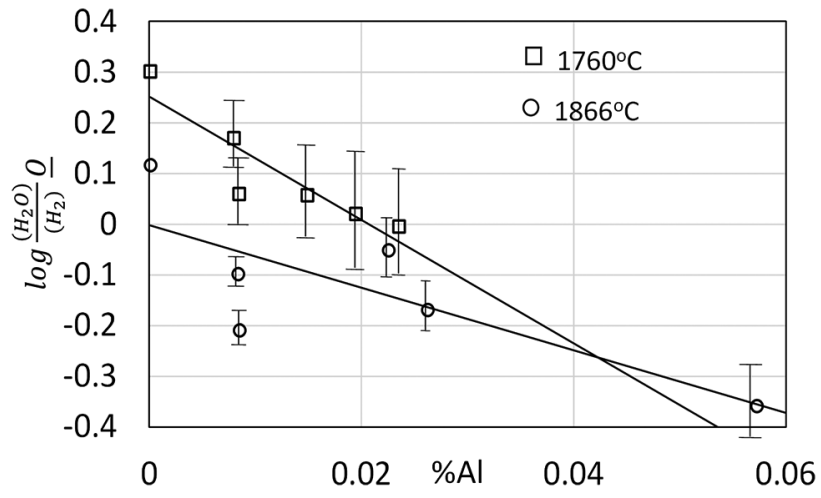

Figure 3. Experimental values measured by [28] of $\log \frac{\left(\mathrm{H}_{2} \mathrm{O}\right)}{\left(\mathrm{H}_{2}\right)} \underline{\mathrm{O}}$

in equilibrium with Fe-Al- $\mathrm{O}$ in $\mathrm{Al}_{2} \mathrm{O}_{3}$ crucibles. The bars indicate an uncertainty of $10 \mathrm{ppm}$ in the oxygen analysis. The slope of the lines represent the interaction coefficient $e_{O}^{A l}$. The graph emphasizes the importance of the accuracy of chemical analysis mentioned in section 2.I.

interaction coefficient. They also indicated clearly that oxygen and aluminum interact in solution in liquid iron (Figure 3 ). Their result is consistent with the observations supported by measurements, and reported since that time, for many other deoxidants in iron (such as $\mathrm{Cr}, \mathrm{V}, \mathrm{C}$ [ I0]). At that time, Chipman [10] proposed a simple physicochemical model for this interaction, in which the deoxidizer would have more ability than iron to "share electrons with the oxygen atoms, thus...tying up oxygen and reducing its activity".

Later, D'Entremont et al. [29] revisited the problem, including in their experiments melts with high aluminum contents. In order to avoid errors in oxygen analysis caused by aluminum vaporization during vacuum fusion analysis, they decided on a different analytical technique. Thus, they took the alumina present at room temperature in the solidified sample as representative of the $\mathrm{Al}$ and $\mathrm{O}$ present in the steel at the experiment temperature. By doing that, they assumed that the solubility of alumina in steel at room temperature is negligible and that no alumina was present in the liquid steel at the experiment temperature. In their experiments they used purified argon (including a step in which argon was passed through a bed of magnesium chips at $550^{\circ} \mathrm{C}$ for final removal of oxygen) and thus avoided oxygen contamination by the atmosphere.

Their results were consistent with the previous measurements for alloys with low aluminum content [28] and resulted in much lower estimates for the interaction coefficients than those shown in Figure 3. Their recommended value was $e_{O}^{A l}=-1.0$ at $1600^{\circ} \mathrm{C}$, obtained by extrapolation. However, their temperature error was reported to be $20^{\circ} \mathrm{C}$. They observed the minimum oxygen content in the range of $0.2-0.5 \% \mathrm{Al}$, depending on the temperature. Interestingly, as they cover the complete binary Fe-Al, their results indicated that the solubility of oxygen in iron in equilibrium with alumina would, after the minimum, pass through a maximum and then decrease at compositions close to pure aluminum as the solvent.
The various works of Chipman and collaborators were performed in induction furnaces, so convection was extensive and the liquid can be assumed homogeneous. There is little spread in the results in the range of low aluminum (before the minimum in oxygen is reached) while this spread apparently increases when one passes this minimum. It is difficult to ascribe the spread specifically to any of the experimental error sources discussed in each case. If, for instance, alumina particles were not properly removed from the liquid, this difficulty should also be experienced at lower aluminum values. It is probable that the variations were caused by a combination of the factors and it can be speculated that the preparation and analysis techniques might have played a significant role, in special when the oxygen and aluminum contents were on the higher range.

Schenk et al. [8] studied the equilibrium with alumina as well as the precipitation kinetics of alumina inclusions in Fe-Al-O alloys. They used purified argon and alumina crucibles to control oxygen contamination. Their analytical methods could only determine Al and O with "satisfactory accuracy" above 10 ppm. Their experiments, however, were mostly performed on conditions in which nucleation barriers for the formation of alumina were present. Fewer experiments were performed under conditions in which $\mathrm{Al}_{2} \mathrm{O}_{3}$ would dissolve in steel to establish equilibrium. They proposed a value $e_{O}^{A l}=-0.22$ at $1600^{\circ} \mathrm{C}$ and the occurrence of the minimum oxygen value at around $2 \% \mathrm{Al}$.

Rohde et al. [9] also investigated the Al-O equilibrium in iron. Their experiments were performed in a Tammann furnace, where convection is limited. To try to circumvent this limitation they have stirred the melt with argon injection, and, at an intermediate point in some of their experiments, "rinsed" the metal with the injection of a small amount of a $\mathrm{CaO}-\mathrm{Al}_{2} \mathrm{O}_{3}$ slag to help remove inclusions from the liquid. Their analysis indicate that, indeed, some $\mathrm{Al}_{2} \mathrm{O}_{3}$ particles were removed. After the slag was introduced, the activity of $\mathrm{Al}_{2} \mathrm{O}_{3}$ was not unity in these slags. One could argue that this could influence the equilibrium, even considering the presence of the pure $\mathrm{Al}_{2} \mathrm{O}_{3}$ crucible. It is also possible that this played a significant role on the scatter of their results (Figure 4 presents their result with slag separated from the results without slag).

More recently, Suito et al. [30] performed similar experiments: instead of argon agitation however, they have used an alumina rod to stir the bath but also used calcium aluminate slags for rinsing. When they corrected Schenk's results for the activity of alumina in the aluminate slags they claim to find good agreement with their results in the high aluminum range. Furthermore, they found reasonable agreement with the thermodynamic calculated equilibrium values when the data of [3I] was used for the interaction coefficients. They also performed a variety of experimental cycles to determine the nucleation supersaturation as well as the equilibrium conditions. Suito and co-workers did a detailed SEM evaluation after the different equilibration cycles to decide whether they were able to eliminate all 


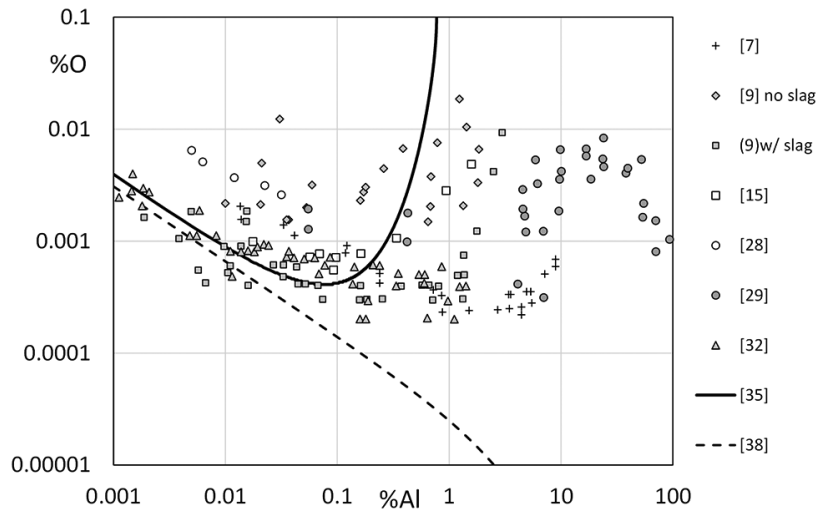

Figure 4. Plot of \%Al vs \%O in steel in equilibrium with $\mathrm{Al}_{2} \mathrm{O}_{3}$. Compilation of experimental data discussed in the text. Data is not at the same temperature in some cases. Solid and dashed lines were calculated with the SLAG3 [32] and TCFE7 [33] models, respectively. SLAG3 model [32] agreement to data is good for values up to approximately $0.24 \% \mathrm{Al}$.

primary alumina inclusions and they were convinced that this had occurred in their experiments.

Fruehan [15] experimental technique differed significantly from other authors in the use of the neutron activation technique for the oxygen analysis. This was due to the concern with $\mathrm{Al}$ effects on the fusion analysis of oxygen first mentioned by D'Entremont et al. [29]. Fruehan emphasizes that the samples analyzed were free of "entrapped" non-metallic inclusions. By this he probably meant large oxide particles, possibly primary deoxidation products. He also followed the reaction using EMF measurements with very good results, in agreement with the assumption that oxygen did not affect the activity of the aluminum. Nonetheless for exact calculations, the results should be corrected to the presently accepted value for the $\mathrm{Cr} / \mathrm{Cr}_{2} \mathrm{O}_{3}$ equilibrium [34], since this mixture was used as reference in his electrolytic cell.

Based on his experimental data Fruehan proposed a value of $e_{O}^{A l}=-0.39$. Later, Kuo [25], however, proposed $e_{O}^{A l}=-0.75$ using Fruehan data, the thermodynamic data of hercinite and the assumption that the minimum oxygen in the hercynite solubility curve must be at the intersection with the alumina solubility curve. So, further uncertainties were introduced in the analysis of Kuo.

Janke and Fischer [35] also used EMF measurements to determine the deoxidation equilibrium in the Fe-Al-O system with good results. However, their total oxygen analysis, which were too high in their own evaluation, did not allow for a good estimation of $e_{O}^{A l}$.

Cho and Suito [36] performed equilibration experiments between iron and $\mathrm{CaO}-\mathrm{Al}_{2} \mathrm{O}_{3}-\mathrm{SiO}$, slags, derived the equilibrium constant for the aluminum deoxidation reaction and proposed a value of $e_{O}^{A l}=-6.83$ at $1600^{\circ} \mathrm{C}$. Their experiments were focused on the low aluminum range, away from the minimum of the $\% A l x \% O$ curve.

More recently, Kang et al. [7] performed a careful equilibration of iron-aluminum alloys with alumina crucibles in a Tammann furnace. The alloys were prepared in advance by pre-melting iron and aluminum inside an $\mathrm{Al}_{2} \mathrm{O}_{3}$ crucible in an induction furnace under $\mathrm{Ar}-3 \mathrm{vol} \% \mathrm{H}_{2}$, to prevent oxygen contamination. Once prepared, $6 \mathrm{~g}$ of the alloy was placed inside an $\mathrm{Al}_{2} \mathrm{O}_{3}$ tube inserted into a mullite tube in a Tammann furnace previously flushed with $\mathrm{Ar}-3$ vol\% $\mathrm{H}_{2}$ to avoid oxygen contamination. The equilibration time was one hour, which according to the authors was enough to reach the equilibrium. They carefully checked the premelted alloy samples to eliminate the primary $\mathrm{Al}_{2} \mathrm{O}_{3}$ inclusions. After the equilibration, they measured the aluminum and oxygen content using inductively coupled plasma atomic emission spectrometry (ICP-AES) and inert gas fusion infrared absorption spectroscopy, respectively. Their results show a lower amount of oxygen than all previously discussed experiments for higher $\mathrm{Al}$ content and a minimum around $2 \%$ Al. They did find a deviation toward higher oxygen values for low Al contents that they could not explain. They also expressed concern for a possible aluminum getter effect in the oxygen analysis, as pointed out by D'Entremont et al. [29]. They proposed a value of $e_{O}^{A l}=-0.174$ for the first order interaction parameter, and included a second order interaction parameter to describe their data.

\section{DISCUSSION}

Figure 4 presents a summary of all experimental data and the results of calculations using two thermodynamic databases with Thermo-Calc. SLAG3 [32] which uses the free energies compiled by Gaye [37] and the interaction coefficients of Sigworth and Elliott [3I] converted as proposed by Hillert [38] and TCFE7 [33] which uses data of preliminary unpublished work by Selleby and Mao, performed in 2007 [33].

The results indicate that in the low aluminum region, where there is little deviation between Henryan activity and composition, the values calculated by TCFE7 and SLAG3 are quite close and agree well with the results of Fruehan [15]. Janke and Fischer [35] as well as Rohde and collaborators results, with slag rinsing [9]. Apparently, the values calculated by SLAG3, based on the dilute solution model are a reasonable prediction up to approximately $0.24 \% \mathrm{Al}$. The occurrence of a minimum in the curve of Figure 4 is not expected by the calculations of TCFE7 while most of the experimental data does show a minimum at some value of \%Al. The various experimental values for this minimum differ significantly, however.

Industrial results for aluminum deoxidation agree well with the values calculated using SLAG3. For higher aluminum steels, such as Nitralloy and similar material, oxygen analysis is scarce or absent in the literature. The comparison with high aluminum nickel based superalloys is not applicable, since these are normally dynamically deoxidized by carbon under vacuum [26], so that the $\mathrm{Al}-\mathrm{O}-\mathrm{Al}_{2} \mathrm{O}_{3}$ equilibrium is never approached. Recently Paek et al. [39] reported 
the industrial results of Yin for total oxygen analysis in a $\mathrm{Fe}-\mathrm{I} .2 \% \mathrm{Al}$ steel slab. The value was in the range of $4 \sim 10 \mathrm{ppm}$ (6 ppm in average), lower than expect by thermodynamic calculations. To elucidate this, Paek and co-workers have oxidized a Fe-9.06\%Al alloy containing I.76 ppm oxygen, by adding a controlled amount of $\mathrm{Fe}_{2} \mathrm{O}_{3}$. They have found that the oxygen content increased and after $\mathrm{Ih}$ and $2 \mathrm{~h}$ reached the equilibrium values calculated by Kang and co-workers [7]. This confirms that the normal industrial practice used for high aluminum steels of adding this element as close to the end of the heat as possible is efficient, if, at this point, there is a lack of oxygen sources to dissolve back into the steel (via the use of stable refractories- both from the thermodynamic and kinetic point of view).

\section{CONCLUSIONS}

The experimental data for the equilibrium of $\mathrm{Al}$ and $\mathrm{O}$ dissolved in $\mathrm{Fe}$ with $\mathrm{Al}_{2} \mathrm{O}_{3}$ shows considerable discrepancy. This is probably related to the high affinity of the two solutes and the related experimental difficulties in measuring this equilibrium at steelmaking temperatures. However, it seems clear that there is a strong interaction between the two solutes in the liquid and that this leads indeed to the occurrence of a minimum in the curve that describes the equilibrium compositions at a constant temperature.

The values predicted by assessed thermodynamic data such as that given by JSPS [24] or that in SLAG3 are sufficiently accurate for the evaluation of the deoxidation of steels (low aluminum steels).

With the increasing interest in low density steels, electrical applications and nitriding alloys, in which one can expect the use of high aluminum contents, the controversy between experimental data and also with theoretical considerations [26] needs to be solved. The slow kinetics of dissolution of modern basic refractories in steels together with the favorable area/volume ratios and appropriate steelmaking practices certainly makes it possible to achieve relatively low total oxygen values with considerable aluminum contents, as reported by Paek et al. [39], by preventing the achievement of equilibrium in industrial conditions. This, however, does not limit the need for a correct understanding of the equilibrium in this very important system.

\section{REFERENCES}

I Llewellyn DT, Hudd RC. Steels: metallurgy and applications. Woburn: Butterworth-Heinemann; 1998.

2 Wang Q, Sun M, Qiu S, Tian Z, Zhu G, Wang L, et al. Study on mold slag with high $\mathrm{Al}_{2} \mathrm{O}_{3}$ content for high aluminum steel. Metallurgical and Materials Transactions. B, Process Metallurgy and Materials Processing Science. 2014;45(2):540-546. http://dx.doi.org/10.1007/s I 1663-013-9929-2.

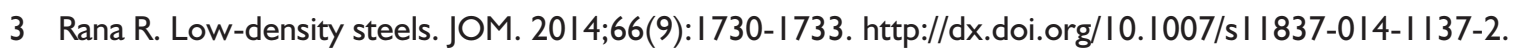

4 Zuazo I, Hallstedt B, Lindahl B, Selleby M, Soler M, Etienne A, et al. Low-density steels: complex metallurgy for automotive applications. JOM. 20 I4;66(9): I747- 1758. http://dx.doi.org/I0. I007/s I I837-0 I4-I084-y.

5 Costa e Silva A, Ågren J, Clavaguera-Mora MT, Djurovic D, Gomez-Acebo T, Lee B-J, et al. Applications of computational thermodynamics: the extension from phase equilibrium to phase transformations and other properties. Calphad. 2007;3I(I):53-74. http://dx.doi.org/10.1016/j.calphad.2006.02.006.

6 Hilty DC, Crafts W. The solubility of oxygen in liquid iron containing aluminum. Transactions of the Metallurgical Society of AIME. 1950; I88(4I4): I8I-204.

7 Kang Y, Thunman M, Sichen D, Morohoshi T, Mizukami K, Morita K. Aluminum deoxidation equilibrium of molten iron-aluminum alloy with wide aluminum composition range at I 873 K. ISIJ International. 2009;49(I0): I483-I 489. http://dx.doi.org//0.2355/isijinternational.49.1483.

8 Schenk H, Steinmetz E, Mehta K. Equilibrium and kinetics of the precipitation of alumina in the system iron-oxygenaluminium at $1600^{\circ} \mathrm{C}$. Archiv für das Eisenhüttenwesen. 1970;4I(2): I3I-I 38.

9 Rohde LE, Choudhury A, Wahlster M. New investigations into the aluminum-oxygen equilibrium in iron melts. Archiv für das Eisenhüttenwesen. 1971;42(3):165- 174.

10 Chipman J. Another look at the problem of steel deoxidation. Metal Progress. 1949;56(2):21 I-22I.

II Wagner C. Thermodynamics of alloys. Reading: Addison-Wesley; 1952.

12 Pelton AD. The polynomial representation of thermodynamic properties in dilute solutions. Metallurgical and Materials Transactions B: Process Metallurgy and Materials Processing Science. 1997;28B(5):869-876. http://dx.doi. org/10.1007/s II663-997-00I5-5.

13 Lupis CHP. Chemical thermodynamics of materials. New York: North-Holland; 1983.

14 Gustafsson S, Melberg P-O. On the free energy interaction between some strong deoxidizers, especially calcium and oxygen in liquid iron. Scandinavian Journal of Metallurgy. I980;9: I I - I I6. 
I5 Fruehan RJ. Activities in liquid Fe-Al-O and Fe-Ti-O alloys. Metallurgical Transactions. 1970; I(I2):3403-34I0. http:// dx.doi.org/I0. I007/BF0303787I.

16 Lupis CHP, Elliott JF. Generalized interaction coefficients. Acta Metallurgica. 1966; I4(4):529-538. http://dx.doi. org/I0.1016/000I-6160(66)90320-8.

17 Pelton AD, Bale CW. A modified interaction parameter formalism for non-dilute solutions. Metallurgical Transactions A, Physical Metallurgy and Materials Science. 1986; 17(7): I2I I-1215. http://dx.doi.org/10.1007/BF02665320.

18 Lukas HL, Fries SG, Sundman B. Computational thermodynamics. Cambridge: Cambridge University Press; 2007.

19 Pelton AD. Solution models. In: Sano N, Lu W-K, Riboud PV, Maeda M, editors. Advanced physical chemistry for process metallurgy. San Diego: Academic Press; 1997. p. 87-II6.

20 St. Pierre GRS. The solubility of oxides in molten alloys. Metallurgical Transactions B: Process Metallurgy. 1977;8B(I):2I5-2 I7. http://dx.doi.org/I0.1007/BF02657649.

2I Kuo C-G. The calculation of Fe-Al-O interaction coefficient. Journal of Alloys and Compounds. 20 I0;494(I-2):7277. http://dx.doi.org/10.1016/j.jallcom.2010.01.035.

22 Hillert M, Selleby M, Sundman B. An assessment of the Ca-Fe-O system. Metallurgical Transactions A, Physical Metallurgy and Materials Science. 1990;2I(I0):2759-2776. http://dx.doi.org/I0.1007/BF0264607I.

23 Lupis CHP, Elliott JF. Generalized interaction coefficients Part II Free energy terms and the quasi-chemical theory. Acta Metallurgica. 1966; I4(9):I019-1032. http://dx.doi.org/I0.1016/000I-6I60(66)90190-8.

24 Hino M, Ito K, editors. Thermodynamic data for steelmaking. Sendai: Tohoku University Press; 2010.

25 Fruehan R, editor. Making, shaping, and treating of steel, steelmaking and refining volume. I Ith ed. Pittsburgh: AISE Steel Foundation; 1998.

26 Hillert M, Selleby M. Solubility of $\mathrm{CaO}$ and $\mathrm{Al}_{2} \mathrm{O}_{3}$ in liquid Fe. Scandinavian Journal of Metallurgy. 1990; 19:23-25.

27 Costa e Silva A. Refractories in vacuum induction melting [master's thesis]. Vancouver: University of British Columbia; 1979.

28 Gokcen NA, Chipman J. Aluminum-oxygen equilibrium in liquid iron. Transactions of the Metallurgical Society of AIME. 1953;194:173-178.

29 D'Entremont JC, Guernsey DL, Chipman J. Aluminum-oxygen interaction in liquid iron. Transactions of the Metallurgical Society of AIME. 1963;227:14-I7.

30 Suito $\mathrm{H}$, Inoue $\mathrm{H}$, Inoue R. Aluminum oxygen equilibrium between $\mathrm{CaO}-\mathrm{Al}_{2} \mathrm{O}_{3}$ melts and liquid iron. ISIJ International. 199|;3 I(I2): I 38I-I388. http://dx.doi.org/I0.2355/isijinternational.3 I. I 38I.

3I Sigworth GK, Elliott JF. The thermodynamics of liquid dilute iron alloys. Metal Science. 1974;8(I):298-310. http:// dx.doi.org/10.1 179/msc.1974.8.1.298.

32 Thermo-Calc Software AB - TCAB. SLAG3 Database. Stockholm; 2012.

33 Thermo-Calc Software AB - TCAB. TCFE7 Database. Stockholm; 2012.

34 Povoden E, Grundy AN, Gauckler LJ. Thermodynamic reassessment of the Cr-O System in the Framework of Solid Oxide Fuel Cell (SOFC) Research. Journal of Phase Equilibria and Diffusion. 2006;27(4):353-362.

35 Janke D, Fischer WA. Deoxidation equilibrium of titanium, aluminum and zirconium in iron melts at $1600 \mathrm{C}$. Archiv für das Eisenhüttenwesen. 1976;47(4): 195-198.

36 Cho S-W, Suito H. Assessment of calcium-oxygen equilibrium in liquid Iron. ISIJ International. 1994;34(3):265-269. http://dx.doi.org//0.2355/isijinternational.34.265.

37 Gaye $\mathrm{H}$, Welfringer J. Modelling of the thermodynamic properties of complex metallurgical slags. In: Fine DRG, editor. Proceedings of the 2nd International Symposium on Metallurgical Slags and Fluxes. Lake Tahoe: TMS-AIME; 1984. p. 357-375.

38 Hillert M. A modified regular solution model for terminal solutions. Metallurgical and Materials Transactions A. 1986; I7A(I0):1878-1879. http://dx.doi.org/10.1007/BF028I7285.

39 Paek M-K, Do K-H, Kang Y-B, Park J-H, Pak J-J. Inclusion thermodynamics for high-Al high-Mn advanced high strength steels. In: Proceedings of Clean Steel in Future - Prof Hae-Geon Lee Symposium; 2012 May 3I-June I; Pohang. Korea: Postech; 2012.

Received: 22 Jun. 2015

Accepted: I4 Sep. 2015 